\title{
Does entrepreneurial confidence influence the nature of entrepreneurial projects chosen by individuals with high ability?
}

\section{Manoj Chandra Bayon*}

School of Business, Universidad Del Norte,

Km 5 via Puerto Colombia, Barranquilla, Colombia Email: bmanoj@uninorte.edu.co Email: bayonmc@gmail.com

*Corresponding author

\section{Esteban Lafuente}

Department of Management, Universitat Politècnica de Catalunya (Barcelona Tech), EPSEB, Av. Gregorio Marañón, 44-50, E-08028 Barcelona, Spain Fax: +34-93-334-8960

Email: esteban.lafuente@upc.edu

\section{Yancy Vaillant}

ESC Rennes School of Business, 2 rue Robert d'Arbrissel CS 76522,35065 Rennes Cedex, France Fax: +33-(0)-2-99-33-08-24

Email: yancy.vaillant@esc-rennes.fr

\begin{abstract}
This empirical study of 247 nascent entrepreneurs examines the joint effect of high ability and entrepreneurial confidence is influencing the choice of innovative entrepreneurship. We suggest that in their decision to pursue entrepreneurship aspiring nascent entrepreneurs seek to gain strategic advantages that allow their new ventures to enter and compete in a given marketplace. We argue that aspiring nascent entrepreneurs create such advantages by choosing innovative entrepreneurial projects as opposed to imitative ones. Our results support the hypothesised effects. Considering that innovation is one of the most important and desired outcome of entrepreneurship our results identifies sources of quality entrepreneurship in an economy.
\end{abstract}

Keywords: innovation; entrepreneurial confidence; entrepreneurial projects; high ability. 
Reference to this paper should be made as follows: Bayon, M.C., Lafuente, E. and Vaillant, Y. (2015) 'Does entrepreneurial confidence influence the nature of entrepreneurial projects chosen by individuals with high ability?', Int. J. Entrepreneurship and Small Business, Vol. 26, No. 2, pp.248-264.

Biographical notes: Manoj Chandra Bayon is an Assistant Professor at the School of Business, Universidad Del Norte (UN), Colombia. He is a Senior Researcher with the Global Entrepreneurship Monitor (GEM) team, Colombia. His area of research interest is human capital, new business creation and strategic management of new firms.

Esteban Lafuente is a Professor in the Department of Management of the Universitat Politècnica de Catalunya (UPC, Barcelona Tech). His research interests include business economics, entrepreneurship and corporate governance. His research documents have been published in the British Journal of Management, Regional Studies, Entrepreneurship and Regional Development, Technovation and Sociologia Ruralis.

Yancy Vaillant is currently an Associate Professor at the ESC School of Business, Rennes, France. He is a graduate of Concordia University, Canada. $\mathrm{He}$ earned his $\mathrm{PhD}$ from the University of Barcelona, Spain. He has post-graduate certificates from both Växjö University, Sweden and the Massachusetts Institute of Technology MIT Sloan School of Management, USA.

\section{Introduction}

Despite the millions of new ventures that are initiated across the world the economic impact of the majority of new ventures is limited (Henrekson and Johansson, 2010). As a result, many have questioned the policy of promoting entrepreneurship that focuses on increasing its quantity as opposed to focusing on identifying and encouraging the formation of quality new ventures (Blanchflower, 2004; Todorovic and McNaughton, 2007; Litwin and Phan, 2012). Such quality, it is argued, is entrepreneurship based on identification/discovery of valuable opportunities as opposed to necessity entrepreneurship (Reynolds et al., 2005) and/or those that lead to job creation (Litwin and Phan, 2012) and introduction of new innovations in the economy (Van Praag and Versloot, 2007). What leads to quality entrepreneurship? In this study, we examine the joint role of founder's ability and entrepreneurial confidence on the choice of quality entrepreneurship. Previous studies have shown that founder's ability plays a significant positive role in entrepreneurial success [refer to Unger et al. (2011) for the meta-analysis]. Such abilities are knowledge, skills and experience of individuals (Becker, 1993). Individuals with high ability are more productive and hence more employable (Becker, 1993). Ceteris paribus in a competitive labour market employed workers have high ability by dint of his or her employability compared to those who are unemployed.

Recent studies also reveal the importance of entrepreneurial confidence on an individual's decision to initiate nascent entrepreneurial activities (Townsend et al., 2010; Bayon et al., 2015). Does entrepreneurial confidence also influence the quality of entrepreneurial projects initiated by these individuals? For instance, are individuals with 
high ability more likely to choose innovative entrepreneurial projects as opposed to imitative ones if they develop entrepreneurial confidence? Although the impact of founder's ability on entrepreneurial entry as well as entrepreneurial outcomes (new venture performance) has been explored previously (Davidsson and Honig, 2003; Rauch and Rijsdijk, 2013; Mayer-Haug et al., 2013) there is a dearth of studies that examine the relationship between individuals' ability and the quality of entrepreneurship in an economy at the earliest stages of the entrepreneurial process. In this paper, we choose innovation as an indicator of quality entrepreneurship and examine if entrepreneurial confidence moderates the effect of founder's ability on the choice of innovative as opposed to imitative entrepreneurial projects. We suggest that while pursuing entrepreneurship aspiring nascent entrepreneurs seek to gain strategic advantages that allow new ventures to enter and compete in a given marketplace. We argue that aspiring nascent entrepreneurs create such advantages by choosing to pursue innovative entrepreneurial projects as opposed to imitative ones.

Through this paper we make three main contributions to the literature on entrepreneurship. Firstly, we determine the entrepreneurial talent that influences the quality of entrepreneurship in an economy, thus adding to the literature on the individual level determinants of quality entrepreneurship (Hvide, 2009). Secondly, by focussing on earliest stages of the entrepreneurial process, i.e., nascent entrepreneurship we provide evidence on entrepreneurial spawning that could be used to gauge the quality of entrepreneurship as opposed to quantity. As evident from several recent studies, more may not be merrier if they do not have the desired impact on the economy (Shane, 2009; Van Praag and Van Stel, 2013). Our study is expected to inform policy makers in addressing the recent quality versus quantity debate in entrepreneurship. Thirdly, by focusing on innovation as an indicator of quality entrepreneurship we provide empirical evidence on the relationship between entrepreneurship and innovation thus complimenting studies that focus on other indicators of quality entrepreneurship like job creation and economic growth (Fritsch and Noseleit, 2013; Naudé, 2014).

The rest of the paper is organised as follows. In Section 2, we discuss the strategic advantages of innovative entrepreneurship as an entry strategy for new ventures followed by hypotheses as to what makes some individuals choose innovative entrepreneurial projects over imitative ones. Section 3 discusses the methodology followed by results in Section 4, discussion in Section 5, implications and contribution in Section 6, limitations and future research in Section 7 and finally the conclusion in Section 8.

\section{Literature review}

\subsection{Innovation and entrepreneurial entry}

The act of new venture creation can be considered as an entrepreneurial project for an enterprising individual who want to exploit a perceived opportunity (Casson and Wadeson, 2007). The first phase of this entrepreneurial project is the time spent in what is commonly known as nascent entrepreneurship (Reynolds et al., 2005). During such a period aspiring (nascent) entrepreneurs evaluate the merit of the perceived opportunity (Dimov, 2010). The merit of a new venture opportunity can be evaluated on the basis of 'strategic advantage' that the perceived opportunity provide to a new venture. This means pursuing an 'opportunity' that not only leads to the creation of feasible products and 
services but also opportunities that provide competitive advantages to the new venture (Ireland et al., 2003). In other words, for any aspiring nascent entrepreneur successful commercialisation of perceived opportunity is contingent not only on the identification of a product or service opportunity but also market positions that the new venture can enter and compete. In this regard aspiring entrepreneurs have the choice of imitation and/or scaling an opportunity already identified by others or innovation, i.e., pursuing a business opportunity that did not exist before. ${ }^{1}$

Why should aspiring nascent entrepreneurs choose innovation as a vehicle for entrepreneurial entry? Entrepreneurial projects based on innovation provide several advantages to new ventures. Firstly, innovation lowers entry barriers (economies of scale) that prevent new and small ventures from entering certain industries (Markides, 2006). Secondly, innovation enhances new venture survival (Helmers and Rogers, 2010). This occurs through the introduction of new product/services in market segments not targeted by incumbent firms thus avoiding competitive retaliation from established (mass market) competitors (Aspelund et al. 2005). Furthermore, through innovation new firms can get a foothold in a segment ignored by more established firms thus providing the possibility of becoming the dominant firms in the future (Christensen, 1997; Markides and Geroski, 2005). Thirdly, innovation can lead to first-mover advantages. By pre-empting competition new ventures can capture the economic rents that accrue to first mover firms (Lieberman and Montgomery, 1988). This in turn could lead to monopoly profit (at least temporary) that raises the future value of successful innovative new ventures (Sorescu and Spanjol, 2008). Evidence also show that innovative firms tend to grow faster than non-innovative firms (De Faria and Mendonca, 2011; Colombelli et al., 2013). The question therefore is what inhibits the choice of innovative entrepreneurship by aspiring nascent entrepreneurs?

Unlike imitative entrepreneurship the choice of innovative entrepreneurship is more risky for several reasons. Firstly, innovation appends business risk over and above the personal risk of entrepreneurship. ${ }^{2}$ For instance, consider the creation of a future market for products/services [Shane and Venkataraman (2000) citing Venkataraman (1997)]. Since the future cannot be predicted with certainty, innovation carries a market risk. Such market risk is the less than the expected product/service demand. Secondly, innovation has financial risk in terms of the upfront investments in research and development (R\&D) or marketing activities (McGrath, 1999). Innovation also has project specific risks. For instance, innovation often require the development of new routines and capabilities which are less transferable across projects (Teece, 2010), while imitative opportunities require replication of what already exist thus making imitative entrepreneurial projects a less costly method to enter a given market. Taken together innovation carries the risks of market demand which may be non-existent or not at the predicted level, costly investments in R\&D and marketing activities whose outcome is known only over time, and project specific risks that could result in sunk investments. On the contrary market risk is limited when product/service is already known to the customers, production process can be replicated or technology is easily available (Koellinger, 2008). The question that follows is what makes innovative entrepreneurship attractive for some aspiring nascent entrepreneurs and not others? We argue that the choice of innovative entrepreneurial projects is attractive if it allows aspiring entrepreneurs to enter, survive and develop long term competitive advantages in the marketplace. In the next section, we 
discuss why some aspiring entrepreneurs more likely to choose innovative entrepreneurial projects to enter the market than others.

\subsection{Ability and innovative entrepreneurship}

According to the human capital theory abilities are a form of capital and individuals' economic well-being is related to his or her abilities (Becker, 1993) through higher wages for those with higher level of abilities (Weiss, 1995). Although ability comprises both formal education and labour market experiences ceteris peribus a positive employment status is an indication of high ability because such abilities are valued by the labour market (Becker, 1993).

However, a positive employment status creates barrier to entrepreneurial entry because of opportunity cost. This opportunity cost is the income that can be earned by staying in employment rather than pursuing entrepreneurship (Raphael et al., 1995). Moreover, continued wage employment provides a stable source of income and lowers income risk due to its relative predictability. In addition to opportunity cost, entrepreneurship also involves the cost of personal assets such as founders' investment capital in their new ventures. Therefore for individuals with high ability, the choice of entrepreneurship requires a return that must cover both the business, and the personal risk of venturing. Since innovative entrepreneurship can enable entry into profitable industry sectors, ensure survival and also lead to competitive advantages it is more likely to compensate for the opportunity cost of entrepreneurship vis-à-vis. wage employment (Cassar, 2006).

However, to undertake the additional risks of innovation individuals need entrepreneurial confidence (Koellinger, 2008). Entrepreneurial confidence arises from the perceived ability to perform the tasks of new venture creation and management (Arenius and Minniti, 2005). Confidence in one's ability is often an antecedent of human action (Akerlof and Shiller, 2009). Benabou and Tirole (2002) suggest that confidence in one's ability provides three functional utility to individuals with low willpower, such as those with high ability. First of all confidence in one's ability provide a consumption utility because by thinking well of one's abilities individuals derive the utility of positive self-image. Secondly, by trusting oneself or believing rightly or wrongly that one possess certain abilities it is easier to convince others. Thirdly, confidence in one's abilities helps in undertaking ambitious goals and persists in the face of adversity. Following Benabou and Tirole (2002), we suggest that the three utility values of confidence, i.e., consumption utility, signalling and motivation utility influences the willingness to choose innovative entrepreneurial projects. Firstly, entrepreneurial confidence could lead to positive affect that in turn influence the ability to respond effectively in dynamic environments such as those encountered in innovative entrepreneurship (Baron, 2008). Secondly, entrepreneurial confidence attracts external stakeholders by signalling the unobservable (productive) abilities of founder(s), for instance the motivation and commitment to undertake the risks of innovative entrepreneurship (Connelly et al., 2011). Thirdly, entrepreneurial confidence could encourage individuals to pursue a more risky, time and resource intensive form of entrepreneurship (Benabou and Tirole, 2002). Therefore, we suggest that individuals with high ability who develop entrepreneurial confidence are more likely to choose innovative entrepreneurial projects compared to those who lack entrepreneurial confidence. 


\section{Data and method}

\subsection{Data and variable definition}

In this study, we use data from the Global Entrepreneurship Monitor (GEM) Adult Population Survey (APS) collected during a three-month period in mid 2012 in Spain. The sample was selected through multiple sampling. In the first stage, a random sample of municipalities divided according to population quota was selected. This was followed by the selection of a random sample of both fixed and mobile telephone number from the telephone directory (annually updated 'Espana Office v5.2' database). In the third stage individuals in the age group between 18 and 64 years were randomly selected. The telephone survey was administered by a professional market research agency selected and monitored by the GEM consortium.

From the original survey of 21,900 observations we identified the subset of those who are classified as nascent entrepreneurs. Nascent entrepreneurs are those who have taken concrete steps towards creating a new firm 12 months preceding the survey (Reynolds et al., 2005). We then considered the employment status of the nascent entrepreneurs. Some nascent entrepreneurs reported working full-time on their new ventures and while some others were pursuing nascent entrepreneurship while keeping their jobs. We remove the nascent entrepreneurs who are pursuing nascent entrepreneurial activities full-time to reduce response bias for one of our independent variables and divide the rest of the sample into nascent entrepreneurs who were also holding on to their jobs (positive employment status) and those who do not have a job (i.e., neither employed or pursuing nascent entrepreneurship) at the time of the survey. The final sample comprises 247 nascent entrepreneurs.

The dependent variable used in this study is innovative entrepreneurship, measured through a self-reported questionnaire item in the GEM APS in which respondents were asked "do all, many or none of your customers consider the product/service new/unfamiliar". Shane (2000) and Koellinger (2008) remark that, in the absence of $\mathrm{R} \& \mathrm{D}$ expenses, this variable is an appropriate proxy measure of innovative entrepreneurship as it captures the entrepreneur's knowledge about customers. Moreover, the ability to identify unique customer need for products/services is one of the fundamental requirements of a new business. From Table 1, we find that in our sample $48.58 \%$ of the respondents report innovative product/services for their target customers.

Table 1 Descriptive statistics for the selected variables

\begin{tabular}{lcccc}
\hline & Mean & Standard deviation & Minimum & Maximum \\
\hline Innovative entrepreneurship & 0.4858 & 0.5008 & 0 & 1 \\
Gender (1 for male) & 0.5992 & 0.4911 & 0 & 1 \\
Age (in years) & 38.5425 & 10.4195 & 18 & 63 \\
Entrepreneurial training & 0.5222 & 0.5005 & 0 & 1 \\
Tertiary education & 0.4170 & 0.4940 & 0 & 1 \\
High ability (employed) & 0.5060 & 0.5009 & 0 & 1 \\
Entrepreneurial confidence (EC) & 0.9109 & 0.2854 & 0 & 1 \\
\hline
\end{tabular}


As for the key independent variables used in this study, we first consider employment status of the respondents at the time of the survey. We take the human capital perspective of ability as propounded by Becker (1993), that considers employed individuals more valuable in terms of their productive ability compared to those who are unemployed. In other words as mentioned previously individuals with positive employment status are individuals with high ability. In our sample $50.60 \%$ of nascent entrepreneurs have positive employment status (employed) (Table 1).

The second explanatory variable measures entrepreneurial confidence by asking respondents if they have the knowledge, skills and experience to pursue entrepreneurship. This self-reported measure has been used in previous studies to assess entrepreneurial confidence (Arenius and Minniti, 2005; Lafuente et al., 2007; Driga et al., 2009; Townsend et al., 2010). In our sample $91.09 \%$ of the respondents have entrepreneurial confidence. It should be noted that such high level of entrepreneurial confidence could be a sign of over-confidence, an overestimation of one's entrepreneurial ability (Koellinger et al., 2007; Moore and Healy, 2008). We also take into account the influence of age, gender, entrepreneurship training and tertiary education on innovative entrepreneurship by using them as control variables in our analytical model.

\subsection{Method}

To test the hypotheses we perform a logistic regression, in which the probability of pursuing innovative entrepreneurship $\left(\operatorname{Pr}\left(Y_{i}=1\right)=\hat{p}_{i}\right)$ is modelled as a function of the aforementioned set of explanatory variables $\left(X_{i}\right)$, where $\hat{p}_{i}$ is expressed as $\hat{p}_{i}=e^{X_{i} \hat{\beta}_{j}} / 1+e^{X_{i} \hat{\beta}_{j}}$, and where the coefficients $\left(\hat{\beta}_{j}\right)$ are estimated by using the maximum likelihood method (Greene, 2003). The model used to test our hypotheses takes the following form:

$$
\begin{aligned}
\text { Innovative entrepreneurship } & =\beta_{0}+\beta_{1} \text { Control Variables }_{i}+\beta_{2} \text { Ability }_{i} \\
& +\beta_{3} \text { Entrepreneurial Confidence }_{i} \\
& +\beta_{23}\left(\text { Ability }_{i} \times \text { Entrepreneurial confidence }_{i}\right)+\varepsilon_{i}
\end{aligned}
$$

In equation (1), $\varepsilon_{i}$ is the logistic distributed error term for the $i^{\text {th }}$ cases. Control variables refer to gender, age, entrepreneurship training and formal education. In the logistic model shown above the effect of the explanatory variables on the dependent variable is determined by the marginal effect $\left(\gamma_{X}\right)$. However, in nonlinear models the interaction effect, i.e., the change in both interacted variables with respect to the dependent variable is not equal to the marginal effect of changing just the interaction term. In addition, the interaction effect in nonlinear models may have different signs for different values of the covariates. Thus, the parameter estimate of the interaction term in nonlinear models does not necessarily indicate the sign of the interaction effect. Therefore, to correctly corroborate our model and measure the impact of our explanatory variables we use the method proposed by Ai and Norton (2003). Through this procedure we obtain robust interaction effects for the variables of interest in which the change in the predicted probability to pursue innovative entrepreneurship results from the double discrete difference with respect to ability variable $\left(x_{2}\right)$ among individuals with entrepreneurial 
confidence $\left(x_{3}\right)$, i.e., $\gamma_{23}=\frac{\Delta^{2} F(X, \beta)}{\Delta x_{2} \Delta x_{3}}$, where $X=x_{2}, x_{3}$. The procedure developed by Ai and Norton (2003) also allows us to test whether the real magnitude of the interaction term is different from zero, $\gamma_{x} \neq 0$, even if the coefficient obtained from the logistic model is not statistically significant. In terms of our hypotheses, we expect that $\gamma_{23}>0$, i.e., individuals with high ability are more likely to pursue innovative entrepreneurship when they develop entrepreneurial confidence.

Finally, we calculate the proportion of correctly classified (predicted) observations as an additional measure of goodness of fit. This is done for the full sample as well as for those individuals that are nascent entrepreneurs and those that are not.

\section{Results}

To test our hypothesis we use two models, first by introducing the independent and control variable additively as shown in model 1 of Table 2 while the results of the model containing the interaction term along with our independent and control variables is shown in model 2. Figure 1(a) and Figure 1(b) is used to interpret the significance of our main interaction term (model 2) of Table 2.

The values of the control variables show that on the one hand age have a negative impact on innovative entrepreneurship, i.e., the partial regression coefficient of age is negative at $p<0.05$, on the other hand entrepreneurship training and tertiary education has significantly positive effect at $\mathrm{p}<0.05$ and $\mathrm{p}<0.01$ respectively, and the corresponding marginal effect are 11.84 and 18.58 percentage points respectively. Therefore, among the four control variables, the effect of tertiary education is most significant and its impact on innovative entrepreneurship is also the highest. However, as shown in Table 2 high ability (a positive employment status) and entrepreneurial confidence individually has no effect on innovative entrepreneurship.

If we examine model 2 in Table 2, we find that the effect of the control variables holds unchanged. However, because of the inclusion of the binary interaction term the regression coefficients (shown in Appendix Table A1) cannot be used to determine the significance of the interaction term. The correct way to determine the magnitude and significance of the interaction term in a model with interaction term is to estimate of the marginal effect of each observation in the sample (Ai and Norton, 2003). ${ }^{3}$ The mean value of this marginal effect $(\mathrm{dy} / \mathrm{dx})$ is shown as model specification 2 in Table 2 . This marginal effect $(\mathrm{dy} / \mathrm{dx})$ is the mean of the interaction effect of all observations in the sample estimated by keeping the values of all other explanatory variables constant at their mean. The estimates $(\mathrm{dy} / \mathrm{dx})$ of the interaction term for each observation and its corresponding Z-value for our main variable of interest (Model 2) is depicted graphically in Figure 1(a) and Figure 1(b). From Figure 1(a), it is seen that the interaction effect for all observations in the sample are positive and the values vary from 0.1042 to 0.4182 . The corresponding z-value vary from 1.44 to 2.022 with a majority of observations in our sample $(80.25 \%)$ having a $\mathrm{z}$-value significant at $\mathrm{p}<0.05$. If we compare model 1 (without interaction term) in Table 2 and the one with the interaction term (model 2) we find that the addition of the interaction term makes the joint effect of high ability and entrepreneurial confidence significantly positive. Considering that high ability has no direct effect on innovative entrepreneurship while its interaction effect is significant and 
positive, our results indicate that those with positive employment status, the ones we consider as having high ability are more likely choose innovative entrepreneurial projects when they have entrepreneurial confidence.

Table 2 Logistic regression: innovative entrepreneurship (average marginal effects)

\begin{tabular}{lcc}
\hline & Model 1 & Model 2 \\
\hline Age (years) & $-0.0065^{* *}$ & $-0.0063^{* *}$ \\
& $(0.0029)$ & $(0.0029)$ \\
Gender (1 for male) & -0.0537 & -0.0645 \\
Entrepreneurship training & $(0.0644)$ & $(0.0642)$ \\
& $0.1184^{* *}$ & $0.1059^{*}$ \\
Education (1 for tertiary education) & $(0.0596)$ & $(0.0596)$ \\
& $0.1858^{* * *}$ & $0.1843^{* * *}$ \\
High ability (1 for employed at the time of survey) & $(0.0618)$ & $(0.0609)$ \\
& -0.0536 & $-0.4511^{* *}$ \\
Entrepreneurial confidence (EC) & $(0.0663)$ & $(0.2275)$ \\
High ability X EC & 0.0436 & -0.2338 \\
Model chi-square & $(0.1069)$ & $(0.1982)$ \\
Log likelihood & & $0.4139^{*}$ \\
Pseudo R & & $(0.2142)$ \\
Correctly predicted (innovative entrepreneurs) & $18.01^{* * *}$ & $21.85^{* * *}$ \\
Correctly predicted (non-innovative entrepreneurs) & -161.0236 & -159.2850 \\
Correctly predicted (full sample) & 0.0589 & 0.0691 \\
Average VIF & 0.6250 & 0.6417 \\
Observations & 0.6378 & 0.6299 \\
\hline
\end{tabular}

Notes: The marginal effect represents the change in the probability as a result of a change in the independent variable. Following equations (1) and (2), the marginal effect of the interaction term for changes in two variables $\left(x_{2}, x_{3}\right)$ are estimated by $\gamma_{x 2, x 3}=\frac{\Delta^{2} F(X, \beta)}{\Delta x_{2} \Delta x_{3}}$. Robust standard errors are presented in brackets. $*, * *, * * *$ indicates significance at the $0.10,0.05$ and 0.01 levels, respectively. 
Figure 1 (a) Interaction term (high ability and entrepreneurial confidence) as a function of the predicted probability of innovative entrepreneurship (b) statistic (Z-value) as a function of the predicted probability of innovative entrepreneurship

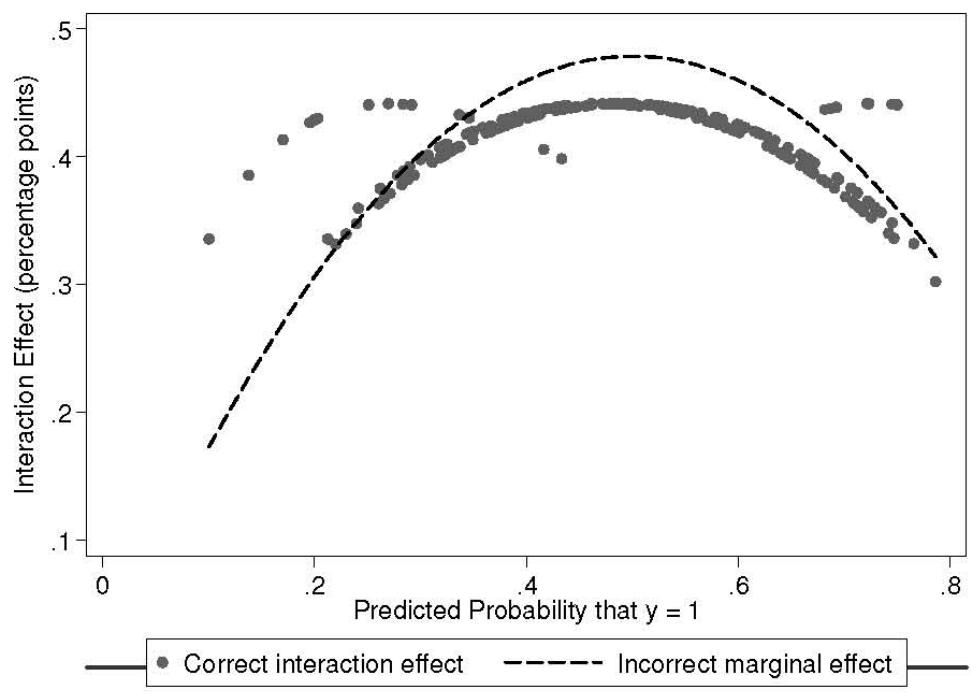

(a)

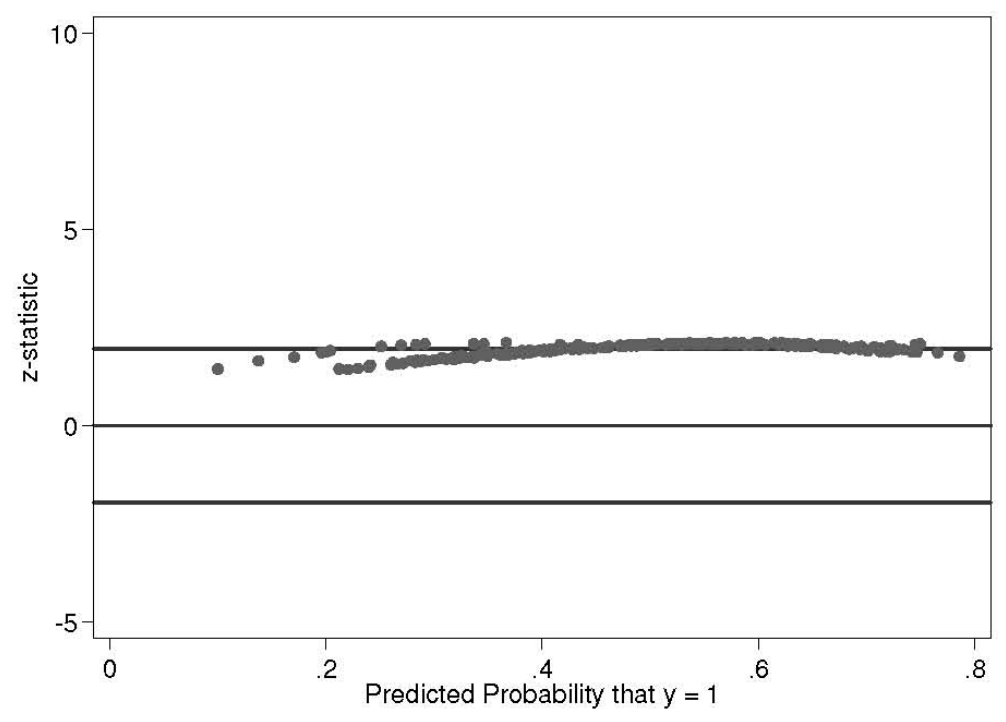

(b) 


\section{Discussion}

The results of our study suggest that innovative entrepreneurial projects are more likely to be chosen by those aspiring nascent entrepreneurs who have high ability and are entrepreneurially confident. We suggested that

1 an aspiring nascent entrepreneurs' choice is driven by the need to gain strategic advantages for the new venture and innovative entrepreneurial projects provide several strategic advantages

2 those with high ability seek to compensate their high opportunity cost in entrepreneurship vis-à-vis. wage employment by choosing innovative entrepreneurial projects when they develop entrepreneurial confidence.

Although previous studies have identified several reasons why employees with high ability leave their jobs for entrepreneurship, for instance compensation structure (Raphael et al., 1995; Carnahan et al., 2015) and the lack of innovation incentive (Hellman, 2007), the results of our study shows when such individuals leave. We show that individuals with high ability consider leaving employment when they develop the confidence that they have the ability to pursue entrepreneurship in a form that could enhance their economic well-being. Our study is also different from those that focus on job creation by new ventures. From an individual level perspective it can hardly be expected that aspiring entrepreneurs would prioritise job creation over the need to realise a perceived opportunity in a way that enable the new (and small) ventures to enter and compete in a given market. Thus, our study prioritises individual need over societal need similar to one suggested by Baumol (1996).

Our results also lends supports the opportunity-based origin of entrepreneurship (Short et al., 2010) by providing evidence that perceived opportunities are opportunities for innovation in the form of products/services which are perceived to be new to a given market. Assuming that such opportunities for innovations are based on private information, what provides the thrust to the new entry decision is the trust reposed on such information by the aspiring entrepreneurs as well as the confidence that they have the ability to execute the task of new venture creation and management. Thus, entrepreneurial confidence among individuals with high ability leads to entrepreneurial action in a form that could be a source of high impact entrepreneurship in an economy. Such high impact entrepreneurship is a source of quality entrepreneurship because helps in filling market gaps, and as our results show individuals with high ability are more likely to be involved in such gap filling activities.

\section{Implications and contribution}

The evidence that high ability leads to innovative entrepreneurship is encouraging. The major implication of our findings on policy making is that our results provide an assessment of quality of entrepreneurial spawning in an economy. Therefore, if policy makers are concerned with improving the quality of entrepreneurship in their regions they should focus on those who follow imitative entrepreneurial projects. Such imitative entrepreneurship is unproductive and adds little economic value (Baumol, 1996) and therefore should not be encouraged (Shane, 2009). In fact entrepreneurship policy could 
be more effective if individuals who pursue imitative entrepreneurial projects are retrained for the labour market rather than entrepreneurship, especially the ones lacking entrepreneurial confidence. We also suggest it might not be necessary to direct support measures to individuals whose choice of entrepreneurship takes advantage of his or her own productive ability, those that are gained through employment experience and the spontaneous drive resulting from entrepreneurial confidence. After all entrepreneurship is an act of individual volition and needs spontaneous drive for undertaking and overcoming the different challenges of the venture creation process.

The managerial implication of our results is that individuals with high ability who act and undertake the risk of innovative entrepreneurial projects signal the financial resource market, for instance angel and other early stage investors about the value of the perceived opportunity. As such innovative entrepreneurial projects pursued by individuals with high ability might not be hampered by lack of resources. In fact the very act of partaking in nascent entrepreneurial activity is sign of entrepreneurial confidence and hence more credible in the eyes of resource providers, not only as a signal of value of the opportunity but also as an indicator of entrepreneurial motivation. Therefore, it is important for aspiring nascent entrepreneurs to take some concrete steps towards innovative entrepreneurship before seeking external resources so that the value of perceived opportunity and entrepreneurial motivation can be projected to outside resources suppliers. We therefore suggest that for individuals with high ability it is a good idea to initiate nascent entrepreneurial activities and then approach the resource market rather than vice-versa.

Our study also provides evidence of the important role played by subjective judgement such as ones' entrepreneurial confidence in entrepreneurial choices especially those involving higher risk like innovative entrepreneurship. While some subjective judgements are well discussed in entrepreneurship literature, for instance opportunity perception (Sarasvathy et al., 2003) and risk assessment (Simon et al., 2000), the role of ability judgement as indicated by entrepreneurial confidence is often ignored. Similarly, although studies based on Lazear's (2005) jack-of-all trade theory refer to the importance of diverse abilities in entrepreneurship, however they ignore the subjective ability judgement necessary for initiating a more risky form of entrepreneurship. This study combines both objective ability and subjective ability to provide new insights into the role of observed and unobserved abilities in influencing quality entrepreneurship.

\section{$7 \quad$ Limitation(s) and future research}

The main limitation of our study is the use of single item measures for operationalising entrepreneurial confidence and innovative entrepreneurship. Although other studies have used similar measures we suggest that future studies should incorporate multi-item measures. In addition our study is based on survey data and uses self-reported perceptions. We do not have an objective way of confirming such perception. Future studies in this area will be strengthened if these measurement issues are taken into consideration.

Our study also opens up new avenues for further research. Our study is mainly focussed on nascent entrepreneurship. Many of the nascent entrepreneurial initiatives may not be converted into operating new ventures. Future studies can explore the role of 
ability and entrepreneurial confidence in the emergence of innovative entrepreneurial ventures, i.e., does such innovative nascent entrepreneurial projects end up in operating new ventures.

\section{Conclusions}

In this paper, we examined the joint effect of high ability and entrepreneurial confidence is influencing the choice of innovative entrepreneurial projects over imitative ones using a dataset of 247 nascent entrepreneurs collected from Spain in 2012. Using recent methodological development in the analysis of interaction effect of logistic regression we find that entrepreneurial confidence does influence the nature of entrepreneurial projects chosen by individuals with high ability. Individuals with high ability are more likely to choose innovative entrepreneurship projects when they develop entrepreneurial confidence.

Our results support the opportunity-based origin of entrepreneurial behaviour. We further extend this literature by showing that such entrepreneurial opportunities are opportunities for innovation. Thus, the result of our study identifies the entrepreneurial talent that could serve as the source of quality entrepreneurship in an economy.

\section{References}

Ai, C. and Norton, E. (2003) 'Interaction items in logit and probit models', Economic Letters, Vol. 80, No. 1, pp.123-129.

Akerlof, G.A. and Shiller, R.J. (2009) Animal Spirits: How Human Psychology Drives the Economy, and Why It Matters for Global Capitalism, Princeton University Press, Princeton.

Arenius, P. and Minniti, M. (2005) 'Perceptual variables and nascent entrepreneurship', Small Business Economics, Vol. 24, No. 3, pp.233-247.

Aspelund, A., Berg-Utby, T. and Skjevdal, R. (2005) 'Initial resources influence on new venture survival: a longitudinal study of new technology-based firms', Technovation, Vol. 25, No. 11, pp.1337-1347.

Baron, R. (2008) 'The role of affect in the entrepreneurial process', Academy of Management Review, Vol. 33, No. 2, pp.328-340.

Baumol, W.J. (1996) 'Entrepreneurship: productive, unproductive, and destructive', Journal of Business Venturing, Vol. 11, No. 1, pp.3-22.

Bayon, M.C., Vaillant, Y. and Lafuente, E. (2015) 'Initiating nascent entrepreneurial activities: the relative role of perceived and actual entrepreneurial ability', International Journal of Entrepreneurial Behavior and Research, Vol. 21, No. 1, pp.27-49.

Becker, G.S. (1993) Human Capital: A Theoretical and Empirical Analysis with Special Reference to Education, University of Chicago Press, Chicago.

Benabou, R. and Tirole, J. (2002) 'Self-confidence and personal motivation', Quarterly Journal of Economics, Vol. 117, No. 3, pp.871-915.

Blanchflower, D.G. (2004) 'Self-employment: more may not be better', Swedish Economic Policy Review, Vol. 11, No. 2, pp.15-74.

Carnahan, S., Agarwal, R. and Campbell, B. (2015) 'The effect of firm compensation structures on employee mobility and employee entrepreneurship of extreme performers', Strategic Management Journal, Vol. 33, No. 12, pp.1411-1430.

Cassar, G. (2006) 'Entrepreneur opportunity costs and intended venture growth', Journal of Business Venturing, Vol. 21, No. 5, pp. 610-632. 
Casson, M. and Wadeson, N. (2007) 'The search for entrepreneurial opportunity', History of Economic Ideas, Vol. 15, No. 1, pp.137-158.

Christensen, C.M. (1997) The Innovator's Dilemma: When New Technologies Cause Great Firms to Fail, Harvard Business School Press, Boston, Massachusetts, USA.

Colombelli, A., Haned, N. and Bas, C.L. (2013) 'On firm growth and innovation: some new empirical perspectives using French CIS (1992-2004)', Structural Change and Economic Dynamics, Vol. 26, No. 1, pp.14-26.

Connelly, B.L., Certo, S.T., Ireland, R.D. and Reutzel, C.R. (2011) 'Signalling theory: a review and assessment', Journal of Management, Vol. 37, No. 1, pp.39-67.

Davidsson, P. and Honig, B. (2003) 'The role of social and human capital among nascent entrepreneurs', Journal of Business Venturing, Vol. 18, No. 3, pp.301-331.

De Faria, P. and Mendonca, J. (2011) 'Innovation strategy by firms: do innovative firms grow more?', International Journal of Entrepreneurship and Small Business, Vol. 12, No. 2, pp.173-184.

Dimov, D. (2010) 'Nascent entrepreneurs and venture emergence: opportunity confidence, human capital, and early planning', Journal of Management Studies, Vol. 47, No. 6, pp.1123-1153.

Driga, O., Lafuente, E. and Vaillant, Y. (2009) 'Reasons for the relatively lower entrepreneurial activity levels of rural women in Spain', Sociologia Ruralis, Vol. 49, No. 1, pp.70-96.

Fritsch, M. and Noseleit, F. (2013) 'Start-ups, long- and short-term survivors, and their contribution to employment growth', Journal of Evolutionary Economics, Vol. 23, No. 4, pp.719-733.

Greene, W. (2003) Econometric Analysis, Prentice-Hall, New Jersey.

Hellmann, T. (2007) 'When do employees become entrepreneurs?', Management Science, Vol. 53, No. 6, pp.919-933.

Helmers, C. and Rogers, M. (2010) 'Innovation and the survival of new firms in the UK', Review of Industrial Organization, Vol. 36, No. 3, pp.227-248.

Henrekson, M. and Johansson, D. (2010) 'Gazelles as job creators: a survey and interpretation of evidence', Small Business Economics, Vol. 35, No. 2, pp.227-244.

Hvide, H.K. (2009) 'The quality of entrepreneurs', The Economic Journal, Vol. 119, No. 593, pp.1010-1035.

Ireland, R.D., Hitt, M.A. and Sirmon, D.G. (2003) 'A model of strategic entrepreneurship: the construct and its dimensions', Journal of Management, Vol. 29, No. 6, pp.963-989.

Koellinger, P. (2008) 'Why are some entrepreneurs more innovative than others?', Small Business Economics, Vol. 31, No. 1, pp.21-37.

Koellinger, P., Minniti, M. and Schade, C. (2007), 'I think I can, I think I can: overconfidence and entrepreneurial behaviour', Journal of Economic Psychology, Vol. 28, No. 4, pp 502-527.

Lafuente, E., Vaillant, Y. and Rialp, J. (2007) 'Regional differences in the influence of role models: comparing the entrepreneurial process of Rural Catalonia', Regional Studies, Vol. 41, No. 6, pp.779-795.

Lazear, E.P. (2005) 'Entrepreneurship', Journal of Labor Economics, Vol. 23, No. 4, pp.649-680.

Lieberman, M.B. and Montgomery, D.B. (1988) 'First-mover advantages', Strategic Management Summer, Special Issue, Vol. 9, No. S1, pp.41-58.

Litwin, A.S. and Phan, P.H. (2012) 'Quality over quantity: reexamining the link between entrepreneurship and job creation', Industrial and Labor Relations Review, Vol. 66, No. 4, pp.833-873.

Markides, C. (2006) 'Disruptive innovation; In need of better theory', The Journal of Product Innovation Management, Vol. 23, No. 1, pp.19-25.

Markides, C. and Geroski, P. (2005) Fast Second: How Smart Companies Bypass Radical Innovation to Enter and Dominate New Markets, Jossey-Bass, San Francisco. 
Mayer-Haug, K., Read, S., Brinckmann, J., Dew, N. and Grichnik, D. (2013) 'Entrepreneurial talent and venture performance: a meta-analytic investigation of SMEs', Research Policy, Vol. 42, Nos. 6/7, pp.1251-1273.

McGrath, R. (1999) 'Falling forward: real options reasoning and entrepreneurial failure', Academy of Management Review, Vol. 24, No. 1, pp.13-30.

Moore, D.A. and Healy, P.J. (2008) 'The trouble with overconfidence', Psychological Review, Vol. 115, No. 2, pp.502-517.

Naudé, W. (2014) 'Entrepreneurship and economic development: theory, evidence and policy', in Currie-Alder, B., Kanbur, R., Malone, D. and Medhora, R. (Eds.): International Development: Ideas, Experience, and Prospects, Oxford University Press, Oxford.

Raphael, A., Muller, E. and Cockburn, I. (1995) 'Opportunity costs and entrepreneurial activity', Journal of Business Venturing, Vol. 10, No. 2, pp.95-106.

Rauch, A. and Rijsdijk, S. (2013) 'The effects of general and specific human capital on long-term growth and failure of newly founded businesses', Entrepreneurship Theory and Practice, Vol. 37, No. 4, pp.923-941.

Reynolds, P., Bosma, N., Autio., Hunt, S., Bono, N.D., Servais, I., Lopez-Garcia, P. and Chin, N. (2005) 'Global entrepreneurship monitor (GEM): data collection, design and implementation', Small Business Economics, Vol. 24, No. 3, pp.205-231.

Sarasvathy, S., Dew, N., Velamuri, S.R. and Venkataraman, S. (2003) 'Three views of entrepreneurial opportunity', in Acs, Z. and Audretsch, D. (Eds.): Handbook of Entrepreneurship Research, pp.141-160, Kluwer Academic Publishers, The Netherlands.

Schumpeter, J.A. (1934) The Theory of Economic Development: An Inquiry into Profits, Capital, Credit, Interest, and the Business Cycle, translated by R. Opie, Harvard University Press, Cambridge, Mass.

Shane, S. (2000) 'Prior knowledge and the discovery of entrepreneurial opportunities', Organization Science, Vol. 11, No. 4, pp.448-469.

Shane, S. (2009) 'Why encouraging more people to become entrepreneurs is a bad policy', Small Business Economics, Vol. 33, No. 2, pp.141-149.

Shane, S. and Venkataraman, S. (2000) 'The promise of entrepreneurship as a field of research', Academy of Management Review, Vol. 25, No. 1, pp.217-226.

Short, J.C., Ketchen, D.J. Jr., Shook, C.L. and Ireland, R.D. (2010) 'The concept of 'opportunity' in entrepreneurship research: past accomplishments and future challenges', Journal of Management, Vol. 36, No. 1, pp.40-65.

Simon, M., Houghton, S.N. and Aquino, K. (2000) 'Cognitive bias, risk perception and venture formation: how individuals decide to start companies', Journal of Business Venturing, Vol. 15, No. 2, pp.113-134.

Sorescu, A. and Spanjol, J. (2008) 'Innovation's effect on firm value and risk: insights from consumer packaged goods', Journal of Marketing, Vol. 72, No. 2, pp.114-132.

Teece, D. (2010) 'Business models, business strategy and innovation', Long Range Planning, Vol. 43, Nos. 2-3, pp.171-194.

Todorovic, Z.W. and McNaughton, R.B. (2007) 'The effect of culture, resources and quality of entrepreneurship on economic development: a conceptual framework', International Journal of Entrepreneurship and Small Business, Vol. 4, No. 4, pp.383-396.

Townsend, D.M,. Busenitz, L.W. and Arthurs, J.D. (2010) 'To start or not to start: outcome and ability expectations in the decision to start a new venture', Journal of Business Venturing, Vol. 25, No. 2, pp.192-202.

Unger, J., Rauch, A., Frese, M. and Rosenbusch, N. (2011) 'Human capital and entrepreneurial success: a meta-analytical review', Journal of Business Venturing, Vol. 26, No. 3, pp.341-358.

Utterback, J.M. and Abernathy, W.J. (1975) 'A dynamic model of process and product innovation', Omega, Vol. 3, No. 6, pp.639-656. 
Van Praag, C.M. and Van Stel, A. (2013) 'The more business owners the merrier? The role of tertiary education', Small Business Economics, Vol. 41, No. 2, pp.335-357.

Van Praag, M. and Versloot, P.H. (2007) 'What is the value of entrepreneurship? A review of recent research', Small Business Economics, Vol. 29, No. 4, pp.351-382.

Venkataraman, S. (1997) 'The distinctive domain of entrepreneurship research', Advances in Entrepreneurship, Firm Emergence and Growth, Vol. 3, No. 1, pp.119-138.

Weiss, A. (1995) 'Human capital vs. signalling explanations of wages', Journal of Economic Perspectives, Vol. 9, No. 4, pp.133-154.

\section{Notes}

1 It should be noted that innovation has been conceptualised using different frames of references, for example, the introduction of new product/service (product/service innovation), new processes or raw materials (process innovation), discovery of new market (disruptive innovation), or business model innovation (Schumpeter 1934; Utterback and Abernathy, 1975; Christensen, 1997; Markides, 2006). In this paper, we use a generic definition of innovation that considers only newness of any of the above as perceived by the individual.

2 Business risks are those that arise from factors that are uncontrollable from the point of view of the individual while personal risks are controllable.

3 The partial regression coefficient and the standard error of the interaction term of high ability and entrepreneurial confidence as shown in Table 2 is an incorrect estimate because it does not take into account the second differentiation of the interaction term [refer to Ai and Norton (2003) for details]. 


\section{Appendix}

Table A1 Logistic regression on innovative entrepreneurship (coefficients only)

\begin{tabular}{lcc}
\hline & Model 1 & Model 2 \\
\hline Age (years) & $-0.0281^{* *}$ & $-0.0277^{* *}$ \\
Gender (1 for male) & $(0.0131)$ & $(0.0133)$ \\
& -0.2336 & -0.2846 \\
Entrepreneurship training & $(0.2816)$ & $(0.2853)$ \\
& $0.5147^{*}$ & $0.4669^{*}$ \\
Education (1 for tertiary education) & $(0.2667)$ & $(0.2688)$ \\
& $0.8078^{* * *}$ & $0.8127^{* * *}$ \\
High Ability (1 for employed) & $(0.2879)$ & $(0.2876)$ \\
& -0.2329 & $-1.9892^{* *}$ \\
Entrepreneurial confidence (EC) & $(0.2905)$ & $(1.0300)$ \\
& 0.1898 & -1.0309 \\
High ability X EC & $(0.4648)$ & $(0.8839)$ \\
& & $1.9151^{*}$ \\
Constant & & $(1.0714)$ \\
& 0.4997 & $1.6820^{*}$ \\
Model chi-square & $(0.6980)$ & $(0.9747)$ \\
Log likelihood & $18.01^{* * *} €$ & $21.85^{* * *}$ \\
Pseudo R & -161.0236 & -159.2850 \\
Correctly predicted (innovative entrepreneurs) & 0.0589 & 0.0691 \\
Correctly predicted (non-innovative entrepreneurs) & 0.6250 & 0.6417 \\
Correctly predicted (full sample) & 0.6378 & 0.6299 \\
Average VIF & 0.6316 & 0.6356 \\
(minimum: maximum) & 1.07 & 4.96 \\
Observations & $(1.01: 1.16)$ & $(1.02: 14.16)$ \\
\hline & 247 & 247 \\
\hline
\end{tabular}

Note: $(*, * *, * *)$ Significant at $1 \%, 5 \%$ and $10 \%$ respectively. 